\title{
SIMPLE DETECTION OF NUTRITIONAL MUSCULAR DYSTROPHY USING THE FLUORESCENCE OF TETRACYCLINES
}

\author{
J. STŘíž
}

\begin{abstract}
Department of Diagnostics, Therapy and Prophylaxis oj Animal Diseases, University of Veterinary Science, 61242 Brno
\end{abstract}

Dedicated to the 50th birthday of Prof. MVDr. P. Jagoš CSc.

Received fanuary 28, 1980

\begin{abstract}
Stř́iž J.: Simple Detection of Nutritional Muscular Dystrophy Using the Fluorescence of Tetracyclines. Acta vet. Brno, 49, 1980: 223-229.

Twelve lambs, 6 to 8-week-old, with clinical signs of nutritional muscular dystrophy of various degrees and duration were given oxytetracycline $\mathrm{i} \mathrm{m}$. in a single dose of $10 \mathrm{mg} / \mathrm{kg}$ body mass. Twenty four hours later the lambs were killed. Upon dissection altogether 136 macroscopically apparent dystrophic deposits and 74 changes of dubious character were found in muscles of 10 lambs; in 2 animals the finding was negative. When irradiated by the UV-light an intensive golden-yellow fluorescence of these dystrophic deposits due to retained oxytetracycline was observed. Using fluorescence, further 17 dystrophic deposits were found, not previously detected by dissection. Out of these, 10 deposits were observed in lambs with indefinite findings, 7 deposits in lambs with negative results of dissection. In some cases the tissue affection was observed to be substantially more pronounced or the deposit scatter to be more frequent than found by dissection. Parallel fluorescence of bones and cartilages did not interfere with the evaluation of dystroptic deposits. The latter did not fluoresce in 3 control lambs without the oxytertacycline application.

The method appears to be convenient and reliable for the detection of dystrophic deposits at varios stages. It does not require complicated equipment.
\end{abstract}

Lambs, nutritional muscular dystrophy, tetracyclines, UV-light, fuorescence.

It has been the aim of veterinary specialists to employ simple, rapid and reliable diagnostic methods. An early diagnosis of disease can, particularly in industrial types of production with high numbers of potentially endangered animals, prevent considerable economic losses. This also applies to our sheep breed where nutritional muscular dystropy has been quite spread. A definite diagnosis of this disease has to be often verified using complex biochemical or histological examinations. Thus, a simplification of this situation is desirable. The described method could contribute to the solution of this pisblem.

Tetracyclines, apart from their antibiotic effect, fossess also other properties, the ability of their increased deposition and persistence in certain tissues of an acceptor organism being one of them. This is due to the formation of chelate bonds with calcium salts, namely with orthophosphate (Saxl, Skoupá and Skoupý 1966), with mucopolysaccharides of chondroitin and hyaluronic acid, with collagen and with other components. Therefore, in organism they will be deposited predominantly in areas where the abovementioned substrates are abundant. The deposition occurs both in physiological (bones) and pathological conditions (inflammatory and dystrophic changes, apart from other hyaline, albumoid or fibrinous degenerative changes, necroses, scleroses, calcification, tumours, etc.) (Málek et al. 1960; Clarke 1965 and others). In such cases the antibiotic concentration was found to be as high as $20-30 \mu \mathrm{g} / \mathrm{g}$ of tissue (McLeay and Welske 1953). Although the tetracyclines are released from other tissues and organs during 24-48 hours, their persistence in areas of deposition is longer, lasting weeks, months and even years (Frost 1960). 
Muscular tissue affected with nutritional muscular dystrophy should, theoretically, enhance the interception and retention of tetracyclines as it is the place where hyaline degeneration, necroses and calcification develop. Another interesting property of tetracycline antibiotics - their ability to fluoresce in UV-light - can be employed for a simple detection of their presence. This ability may be accounted for by the presence of naphtacenecarboxamine nucleus. Fluorescence is very intensive and is dependent on $\mathrm{pH}$, the neutral reaction being most suitable. The wavelength of oxytetracycline or tetracycline fluorescence is within $365-366 \mathrm{~nm}$ and is of yellow or golden-yellow colour, that of chlorotetracycline being almost blue. The lower detection limit of tetracycline by fluorescence method was reported to be at concentration $1 \mu \mathrm{g} / \mathrm{g}$ of tissue (Málek 1963) while according to other authors this value is even lower (Střiž 1972).

The practical application of the above described properties has been the purpose of our experiments.

\section{Materials and Methods}

Out of four flocks of Stavropol Merino sheep, in which local veterinary service diagnosed nutritional muscular dystrophy (NMD), altogether 15 lambs, 6 to 8-week-old, were selected on the basis of clinical examination and divided into three groups as follows: 6 lambs with distinct clinical manifestation of NMD, further 6 lambs suspect of this disease (slight movement difficulties) and 3 lambs also with pronounced manifestation of NMD (serving as controls). The extent of disease was from several days to two weeks. The experimental lambs were given a single dose of oxytetracycline in form of preparation „Oxymykoin inf. ad. us. veter. Spofa" in amount of $10 \mathrm{mg} / \mathrm{kg}$ of body mass i. m. Both the experimental and control animals were killed after 24 hours and dissection was carried out directed at macroscopically apparent pathomorphological changes caused by NMD. The lambs or their organs and tissues were then examined, also macroscopically, in the dark room, using UV-light. An OSRAM HBQ $125 \mathrm{~W}$ UV source powered by $220 \mathrm{~V}$ a. c. with a transformer and choke in series was used. The illuminated tissues were placed in a distance of $45 \mathrm{~cm}$ from the lamp. The photographs of objects were taken using a colour ORWO 16 Din film, exposure 25 ", aperture 8, covering the lens with yellow filter. Always two lamps were used for photographing whereas one lamp was adequate for an adspection evaluation. Final$1 y$, fluorescence and dissection findings were compared.

\section{Results}

The dissection finding in all lambs of group I (No. 1-6) with clear clinical manifestation was positive. Altogether 78 macroscopically apparent dystrophic deposits and 51 not quite explicit changes were found in muscles. In group II (lambs No. 7, 8, 11 and 12) with only a suspect NMD there were 58 perceptible and 23 indefinite pathological changes, in two lambs of this group (No. 9 and 10) the dissection finding being negative. Later, a pelvis contusion was found to be the cause of movement difficulties in lamb No. 10.

Upon UV-light irradiation an intensive fluorescence appeared in all deposits denoted as unequivocally dystrophic by dissection. Apart from this, further 17, mostly smaller, disseminated deposits (of these 7 in lamb No. 9, negative on dissection) were determined by means of fluorescence. Out of 74 deposits, marked as indefinite, the fluorescence was observed only in 62 cases, being, nevertheless, of the same intensity as in deposits with perceptible changes. The rest of them, 12 areas denoted by dissection, did not fluorescence so that an assumption can be made that the changes were of different character (not depositing tetracyclines) 

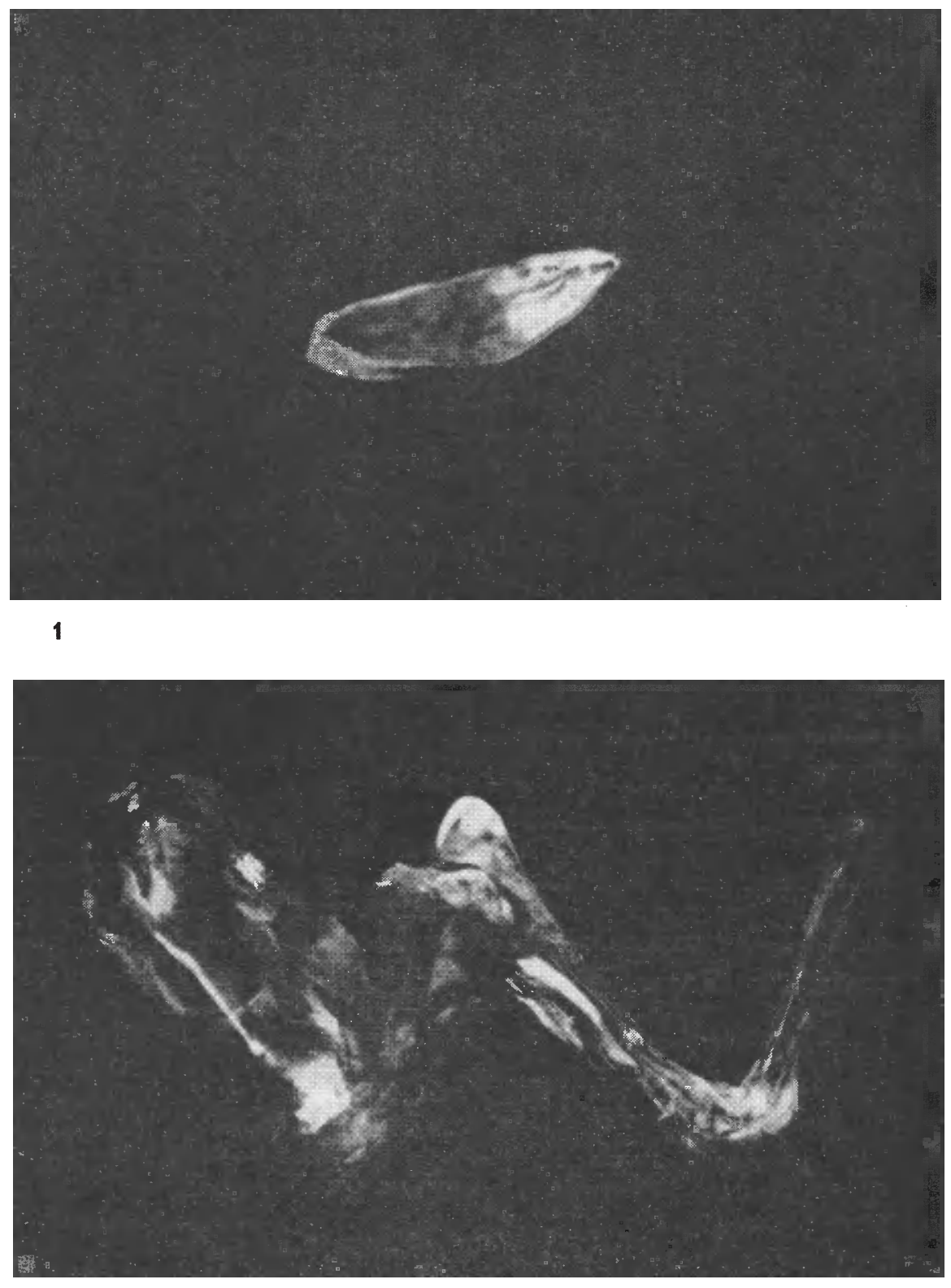

2 


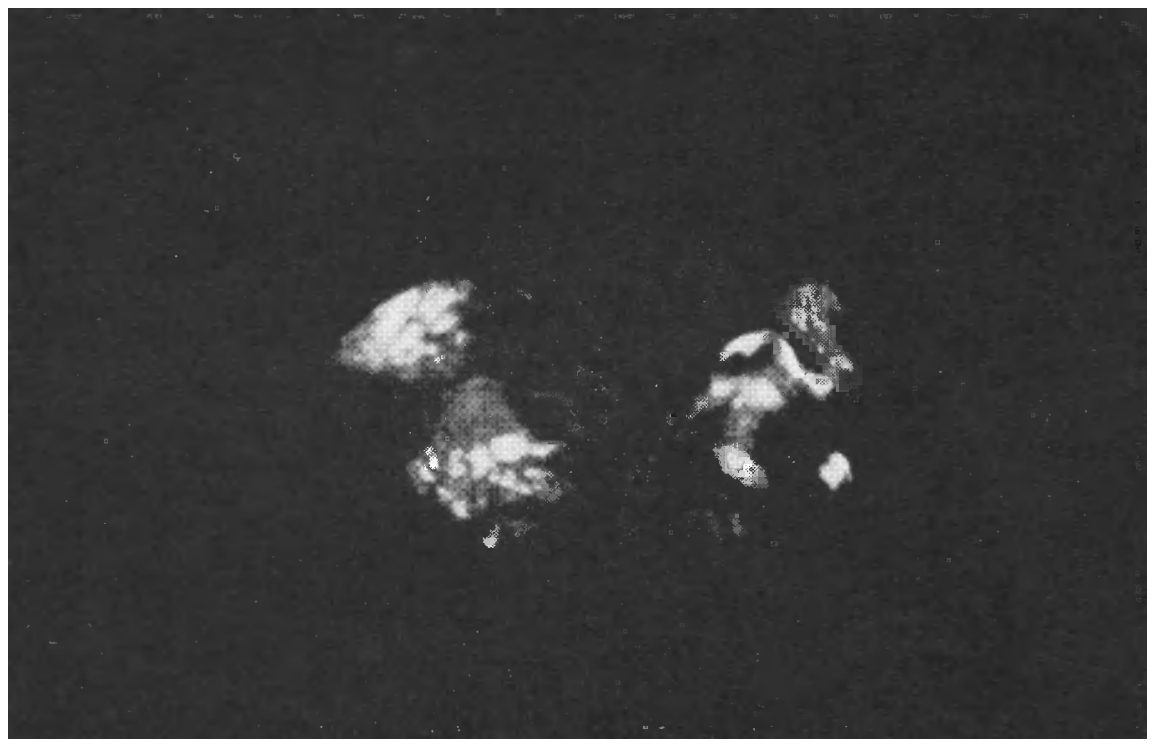

3

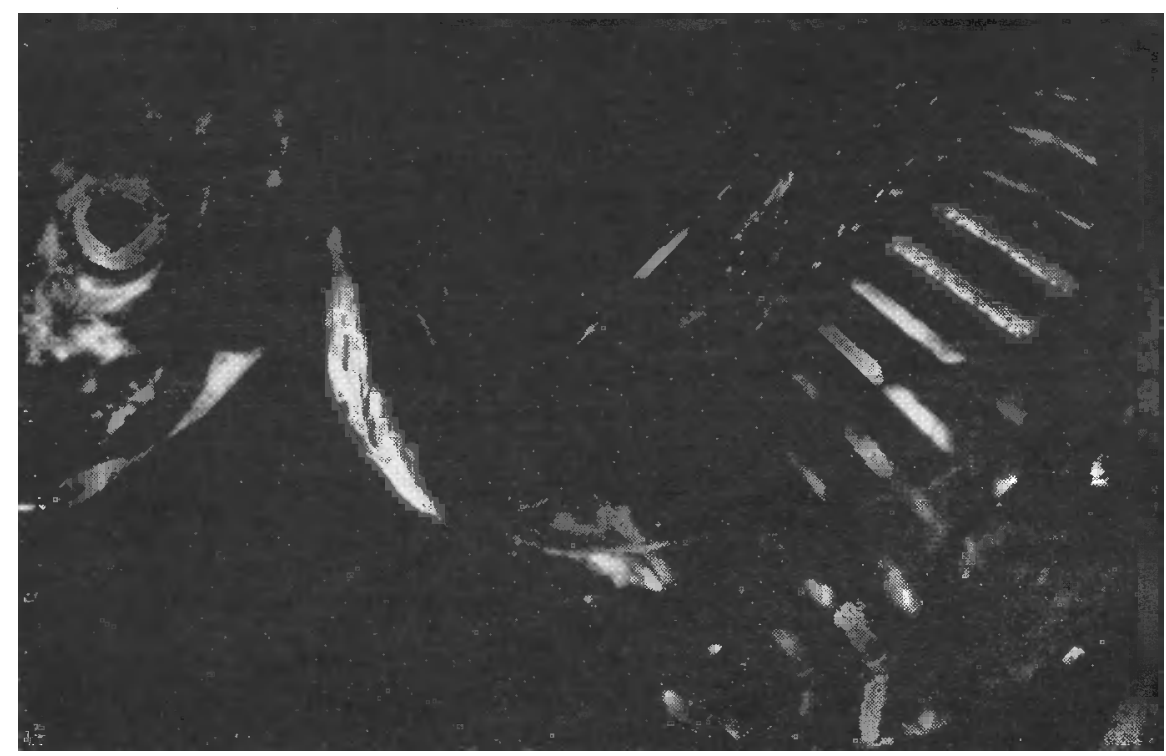

4

Photographs 1-4: Fluorescence of tetracycline in dystrophic deposits of lamb No. 8 
or the matter could lie in subjectively evaluated artefacts, their differentiation being difficult by dissection. It was further observed by fluorescence examination that the tissue affection was substantially more spread in 44 deposits than was found by adspection at dissection. A survey of the described findings is given in the following table:

Table 1

Number of dystrophic changes in muscles found by dissection and fluorescence

\begin{tabular}{|c|c|c|c|c|c|}
\hline \multirow{3}{*}{$\begin{array}{c}\text { Number of lambs } \\
\text { with clinical } \\
\text { manifestations }\end{array}$} & \multicolumn{4}{|c|}{ Number of dystrophic changes found by } & \multirow{3}{*}{ Note } \\
\hline & \multirow{2}{*}{ dissection } & \multicolumn{3}{|c|}{ fluorescence } & \\
\hline & & confirmed & not confirmed & newly found & \\
\hline $\begin{array}{c}\text { With oxytetracycline } \\
10 \\
1 \\
1 \\
\text { Without oxytetracycline } \\
3\end{array}$ & 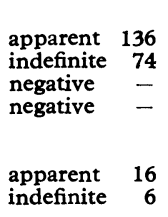 & $\begin{array}{r}136 \\
62 \\
- \\
-\end{array}$ & $\begin{array}{l}\overline{12} \\
-\end{array}$ & $\begin{array}{r}\overline{10} \\
7 \\
-\end{array}$ & $\begin{array}{l}\text { pelvis } \\
\text { contusion }\end{array}$ \\
\hline
\end{tabular}

Fluorescence of dystrophic deposits in lamb No. 8 (with slight clinical signs and indefinite dissection finding) can be seen on Figures 1-4. A marked fluorescence of deposits can be observed on the muscle surface and cuts of tongue, in myocardium of both cardiac ventricles and in musculus longissimus dorsi; $\mathrm{m}$. cleidomastoideus on the neck, $\mathrm{m}$. extensor carpi radialis and $\mathrm{m}$. extensor digitalis communis on the foreleg, $\mathrm{m}$. teres minor and $\mathrm{m}$. infraspinatus on the scapula also fluoresce. Well perceptible fluorescence of bones and cartilages (in this case partly bluish autofluorescence) does not interfere with the evaluation of other tissues and organs.

16 positive and 6 dubious deposits have been identified in three control animals without the oxytetracycline administration. None of them fluoresced in UV-light.

\section{Discussion}

The results have confirmed that when nutritional muscular dystrophy is present the oxytetracycline was intensively intercepted and deposited. Using fluorescence, these deposits can, therefore, be detected, their localization, frequency and the extent of tissue affection unambiguously determined, confirming thus unequivocally a diagnosis of nutritional muscular dystrophy. This fact is valuable in diagnostically controversial cases when other affection of bone and muscle system or other diseases (rachitis, arthritis, tendinitis, lesions, nervous system disorders, enzootic ataxia or other deficiency conditions, poisoning, etc.) has to be excluded. Even when the muscle tissue itself is affected by other processes, e. g. ulcers, necroses, rheumatic or traumatic myositis, etc., there is no danger of wrong evaluation if we take into consideration a specific localization of fluorescence findings in NMD. Only in the case of negative finding, observed both clinically and upon dissection and, moreover, by fluorescence examination, relevant biochemical and histological examinations can be carried out. Microscopical fluorescence examination of affected tissues is also possible; it further broadens the application possibilities of fluorescence but since it is more laborious and demanding as far as 
material equipment is concerned we have not applied this method. Lamb No. 9 serves a practical example of our experiments. The results of basic examinations (clinical and dissection) of this animal did not facilitate an unequivocal diagnosis. Fluorescence, however, emphasized typical changes and the diagnosis could be confirmed without further complicated examination. Negative results of dissection and fluorescence finding in lamb No. 10 helped to reveal the cause of movement difficulty (pelvis lesion) and helped, therefore, to establish the correct diagnosis.

The method can also be used in moribund lambs since the penetration and fixation of tetracyclines in affected areas is rapid; according to Málek (1962) it starts within several seconds or minutes; 60 minutes later it is intensive. However, at least partly operative blood circulation (so that resorption and transport of tetracyclines to dystrophic sites is not inhibited) is a necessary condition in these lambs. A suitable time to carry out a fluorescence examination is considered to be 24-48 hours after antibiotic application. A later examination can, of course, be carried out as dystrophic changes together with retained tetracyclines are known to persist in affected muscle for rather a long time (Žák et al. 1963). Lambs affected by this disease for a longer period of time can be examined as well.

The described method is simple, easily carried out, applicable either independently or as an auxiliary method for diagnosis confirmation and NMD detection. It requires minimal equipment and no complicated laboratory examinations. The evaluation of fluorescence findings - although subjective - is unequivocal in most cases, the disease interception is good even in cases where normal macroscopic dissection yields no clear results. The possibility of confusion in diagnosis is negligible because conditions inducing the same fluorescence effect in lamb tissues as NMD practically does not exist. Furthermore, the diagnosis can usually be complemented by history and clinical findings.

\section{Jednoduchý průkaz nutriční svalové dystrofie pomocí fluorescence tetracyklinů}

U 12 jehňat ve stáři $6-8$ týdnů s klinickými př́iznaky nutriční svalové dystrofie rưzného stupně a trvání byl jednorázově aplikován oxytetracyklin v dávce $10 \mathrm{mg} / \mathrm{kg}$ ž. hm. i. m. Za 24 hodin byla jehňata odporažena. Při pitvě bylo u 10 jehňat nalezeno ve svalech celkem 136 makroskopicky patrných dystrofických ložisek a 74 změn dubiózního charakteru, u 2 jehňat byl nález negativní. Při ozárení UV-světlem fluoreskovala tato dystrofická ložiska intenzívně zlatožlutě zadrženým oxytetracyklinem. Kromě toho bylo pomocí fluorescence nalezeno dalších 17 dystrofických ložisek, běžnou pitvou nezachycených, $\mathrm{z}$ toho $10 \mathrm{u}$ jehňat $\mathrm{s}$ pitevním nálezem neurčitým a 7 u jehněte pitevně zcela negativního. U některých ložisek fluorescence ukázala podstatně rozsáhlejší postižení tkání nebo četnější rozsev ložisek než bylo stanoveno běžnou pitvou. Souběžná fluorescence kostí a chrupavek nebránila posuzování nálezů. U 3 kontrolních jehňat bez aplikace oxytetracyklinu dystrofická ložiska nefluoreskovala.

Metoda se jeví vhodnou pro snadný a jistý průkaz dystrofických ložisek v různém stadiu. Vyžaduje jen jednoduché vybavení. 


\section{Простая идентификация алиментарной мышечной листрофии с помощью флуоресценции тетрациклинов}

У 12 ягнят в возрасте 6-8 недель, с клиническими признаками алиментарной мышечной дистрофии разной степени и продолжительности, единовременно вводился окситетрациклин дозой 10 мг/кг живого веса внутримышечно. В течение суток ягнята были забиты. При вскрытии у 10 ягнят было в мышцах найдено в итоге 136 макроскопически видных дистрофических очагов и 74 изменений сомнительного характера, диагноз у 2 ягнят был отрицательный. При облучении ультрафиолетовым светом данные дистрофические очаги флуоресцировали золотисто-желтым цветом, задержанным окситетрациклином. Помимо этого с помощью флуоресценции было найдено следующих 17 дистрофических очагов, обычным вскрытием не установленных, из этого 10 у ягнят с неопределенным диагнозом вскрытия и 7 у ягнят с диагнозом вскрытия отрицательным. У некоторых очагов флуоресценция выявила более широкое поражение тканей или частое рассеивание очагов по сравнению с определением в ходе обыкновенного вскрытия. Одновременная флуоресценция костей и хрящей не препятствовала оценке диагноза. У 3 контрольных ягнят без примемения окситетрациклина дистрофические очаги не флуоресцировали.

Метод является подходящим для несложной и уверенной идентификации дистрофических счагов на разной стадии. Он сопряжен лишь с простым оснащением.

\section{References}

CLARKE, J. A.: A microscopic study of tetracycline localisation in otosclerotic stapes. J. Laryng., 79, 1965: 300-304.

PROST, N. M.: An economical microfluorescence set-up for detection of tetracyclines in bone. Henry Ford Hosp. Med. Bull., 8, 1960: 197-198.

MÁLEK, P., - KOLC, J.: Penetration of chlortetracycline in tissue affected by pathological changes. Antibiot. and Chemother., 10, 1960: 488-494.

MÁLEK, P.: Tetracyklinová antibiotika v organismu. Nakl. Čs. akademie věd, Praha, 1962, $300 \mathrm{pp}$.

SAXI, O. - SKOUPÁ, M. - SKOUPÝ, M.: Vedlejší účinky lékủ. IV. Poškození plodu léky. Lék. věda v zahraničí, 1966: 151-156.

STŘíŽ, J.: Studium některých otázek účinku oxytetracyklinu při sípavce prasat. $\mathrm{Ph}$. D. Thesis, Brno $1972,132 \mathrm{pp}$.

ŽÁK, F. - MÁLEK, P. - ZÁSTAVA, V. - KOLC, J.: K otázce dlouhodobého přetrvávání tetracyklinových antibiotik v organismu za patologických stavů. Čas. Lék. čes., 102, 1963: 902 to 906 . 